\title{
ZEB1 wt Allele
}

National Cancer Institute

\section{Source}

National Cancer Institute. ZEB1 wt Allele. NCI Thesaurus. Code C105606.

Human ZEB1 wild-type allele is located in the vicinity of 10p11.2 and is approximately 214 $\mathrm{kb}$ in length. This allele, which encodes zinc finger E-box-binding homeobox 1 protein, plays a role in the transcriptional repression of interleukin-2 gene expression. Mutations in this gene are associated with both posterior polymorphous corneal dystrophy-3 and late-onset Fuchs endothelial corneal dystrophy. 